\title{
Correction to: Dapaglifozin: A Review in Symptomatic Heart Failure with Reduced Ejection Fraction
}

\author{
Hannah A. Blair ${ }^{1}$ \\ Published online: 2 December 2021 \\ (c) Springer Nature 2021

\section{Correction to: \\ American Journal of Cardiovascular Drugs (2021) 21:701-710 https://doi.org/10.1007/s40256-021-00503-8}

The article titled "Dapagliflozin: A Review in Symptomatic Heart Failure with Reduced Ejection Fraction", written by Hannah A. Blair was originally published Online First without open access. After publication in volume 21, issue 6 , pages 701-710, the Authors requested that the article be made an open access publication on November 23rd. Open access for this paper was funded by AstraZeneca.

This article is licensed under a Creative Commons Attribution-NonCommercial 4.0 International License, which permits any non-commercial use, sharing, adaptation, distribution and reproduction in any medium or format, as long as you give appropriate credit to the original author(s) and the source, provide a link to the Creative Commons licence, and indicate if changes were made. The images or other third-party material in this article are included in the article's Creative Commons licence, unless indicated otherwise in a credit line to the material. If material is not included in the article's Creative Commons licence and your intended use is not permitted by statutory regulation or exceeds the permitted use, you will need to obtain permission directly from the copyright holder. To view a copy of this licence, visit http://creativecommons.org/licenses/by-nc/4.0/.

The original article has been corrected.

Open Access This article is licensed under a Creative Commons Attribution-NonCommercial 4.0 International License, which permits any non-commercial use, sharing, adaptation, distribution and reproduction in any medium or format, as long as you give appropriate credit to the original author(s) and the source, provide a link to the Creative Commons licence, and indicate if changes were made. The images or other third party material in this article are included in the article's Creative Commons licence, unless indicated otherwise in a credit line to the material. If material is not included in the article's Creative Commons licence and your intended use is not permitted by statutory regulation or exceeds the permitted use, you will need to obtain permission directly from the copyright holder. To view a copy of this licence, visit http://creativecommons.org/licenses/by-nc/4.0/.
The original article can be found online at https://doi.org/10.1007/ s40256-021-00503-8.

Hannah A. Blair

demail@ springer.com

1 Springer Nature, Mairangi Bay, Private Bag 65901, Auckland 0754, New Zealand 